
reservoir: a case study from the campi

SUBJECT AREAS:

GEOCHEMISTRY

VOLCANOLOGY

SOLID EARTH SCIENCES

PETROLOGY

Received

1 August 2012

Accepted

17 September 2012

Published

5 October 2012

Correspondence and requests for materials should be addressed to L.P. (lucia. pappalardo@ov.ingv. \section{flegrei caldera}

\author{
Lucia Pappalardo \& Giuseppe Mastrolorenzo
}

Istituto Nazionale di Geofisica e Vulcanologia, Sezione di Napoli Osservatorio Vesuviano Via Diocleziano, 328, I-80124 Napoli, Italy.

In recent decades, geophysical investigations have detected wide magma reservoirs beneath quiescent calderas. However, the discovery of partially melted horizons inside the crust is not sufficient to put constraints on capability of reservoirs to supply cataclysmic eruptions, which strictly depends on the chemical-physical properties of magmas (composition, viscosity, gas content etc.), and thus on their differentiation histories. In this study, by using geochemical, isotopic and textural records of rocks erupted from the high-risk Campi Flegrei caldera, we show that the alkaline magmas have evolved toward a critical state of explosive behaviour over a time span shorter than the repose time of most volcanic systems and that these magmas have risen rapidly toward the surface. Moreover, similar results on the depth and timescale of magma storage were previously obtained for the neighbouring Somma-Vesuvius volcano. This consistency suggests that there might be a unique long-lived magma pool beneath the whole Neapolitan area.

arge-volume silicic caldera systems have produced some of the largest explosive eruptions in the world. The generation of these large magmatic systems, their mechanisms of differentiation, and the timescale of overpressuring and opening are crucial issues for volcanic risk evaluation, particularly in densely populated areas.

The Campanian Volcanic Zone developed within the graben of the Campanian Plain, which formed during the Plio-Pleistocene epoch as a consequence of an extensional system likely related to the final stages of the opening of the southern Tyrrhenian Sea. Geothermal boreholes drilled north-west of the Campi Flegrei caldera revealed that widespread effusive volcanism characterised by calc-alkaline andesitic and basaltic compositions occurred within the Plain approximately 1.5 Ma ago. More recently, in the last $300 \mathrm{ka}$, widespread volcanic activity fed by alkaline magmas has taken place within the southern part of the Campanian Plain, especially in the last 50 ka on the Vesuvius central volcano and in the Campi Flegrei, Ischia and Procida volcanic fields. The composition of the eruptive products has been practically unchanged throughout this time, which suggests that a wide alkaline magmatic source has been active up to recent times. The largest part of the magma volume was erupted from central and fissure vents in a zone presently cantered in the Campi Flegrei caldera and its surroundings, the most active part of this long-lived plumbing system.

During its eruptive history, the high-risk Campi Flegrei volcanic district west of Naples emitted ca $400 \mathrm{~km}^{3}$ of alkaline magmas in a variety of eruptions ranging from low Volcanic Explosivity Index (VEI < 3) events, generally supplied by less-evolved magmas, to super-eruptions involving chemically differentiated magmas. A wide low velocity layer, interpreted as an extended magmatic body, has been detected by seismic tomography at 8-10 km beneath the Campi Flegrei caldera and the neighbouring Vesuvius volcano ${ }^{1,2}$. To investigate the likely state of this wide plumbing system, we have tracked the pre-eruptive and eruptive history of the magmas by studying the geochemical (matrix-glass compositions), isotopic (oxygen isotope compositions of separated minerals) and textural (crystal number density and size distributions) features of representative rock samples collected from volcanic deposits from past eruptions in Campi Flegrei. The data were compared to data that were previously acquired ${ }^{3}$ for Somma-Vesuvius volcanic rocks in order to explore the possible relationship between the two feeding systems.

\section{Results}

Magma evolution in crustal reservoirs. The major element concentrations of matrix glasses in the samples range from mafic trachybasalt to felsic trachyte (Figure 1, Table 2). Felsic compositions are generally represented by pumice samples collected from deposits of highly explosive eruptions (VEI 4-7), with the exception of the scoria 


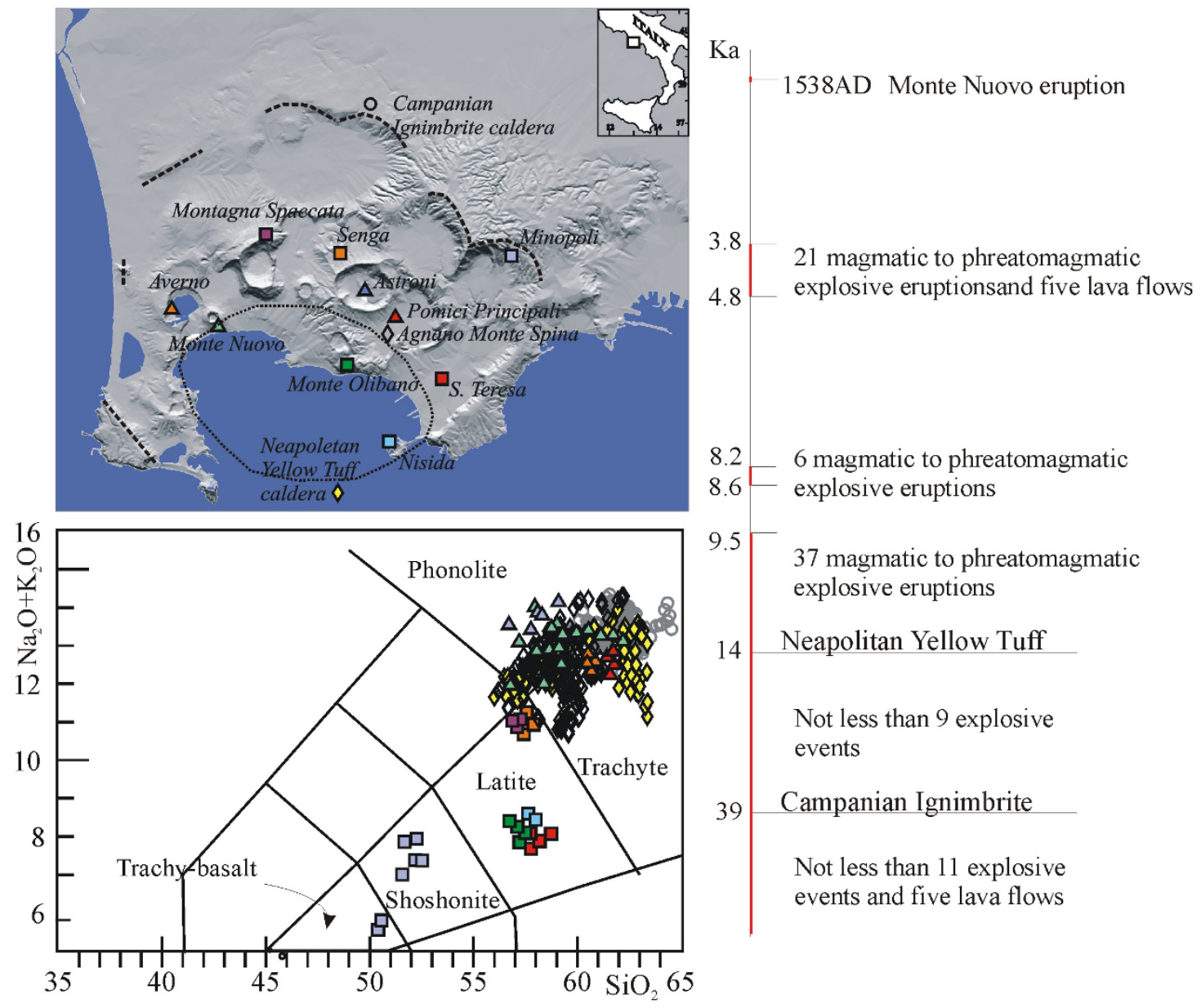

Figure 1 The Campi Flegrei volcano, showing the location of vents of the studied eruptions. Bold dashed lines: vent of Campanian Ignimbrite eruption presumed on the basis of geological evidence ${ }^{51}$, dotted line: Neapolitan Yellow Tuff caldera hypothesized on the basis of geophysical data ${ }^{52}$. Right: schematic chronogram of Campi Flegrei activity as recorded by stratigraphic successions. Bottom: plot of total alkalis vs. silica for Campi Flegrei studied rocks; symbols correspond to the vent locations on map.

samples produced by the strombolian Monte Nuovo eruption. Pumice samples are nearly aphyric (1-5\% crystals), highly vesiculated (70\%), with microlite-poor or microlite-free groundmass. In contrast, mafic compositions typically occur in scorias from strombolian eruptions (VEI 2-3). These are relatively dense, with $40-60 \%$ vesicularity, high (20-30\%) phenocryst contents, and a groundmass generally containing abundant feldspar microlites ( $<100$ micron) (Figure 2, Table 3).

Previous isotopic investigations (e.g. ${ }^{4}$. and references therein) have indicated that these co-genetic mafic and felsic rocks developed by crystal-liquid fractionation associated with a minor amount of crustal assimilation in a multi-level magma reservoir. Felsic magmas occupied an upper zone of crystal-poor buoyant melt located between 250-150 Mpa according to thermo-dynamical modelling and phase-equilibrium experiments ${ }^{5,6}$, and were supplied by a deeper crystal-rich mafic layer. In addition, a minor amount of limestone assimilation during magma differentiation has been inferred on the basis of isotopic studies on Campanian magmas ${ }^{2,7}$. Such crustal contamination processes, leading to the generation of $\mathrm{CO}_{2}$-rich fluid

Table 1 | Studied Campi Flegrei volcanic formations

\begin{tabular}{lccll} 
Volcanic Formation & VEI & Age $(\mathrm{Ka})$ & Volcanological features & Composition \\
\hline Campanian lgnimbrite & 7 & 39 & low aspect ratio ignimbrite & trachyte/phonolite \\
Neapolitan Yellow Tuff & 6 & 14 & wet pyroclastic surge & latite-trachyte \\
Agnano Monte Spina & 5 & 4.1 & pyroclastic flow & trachyte \\
Pomici Principali & 4 & 10.3 & plinian fallout deposit & latite/trachyte \\
Astroni & 4 & 3.8 & tuff ring & trachyte \\
Minopoli & 3 & 11 & strombolian deposit & trachybasalt \\
Baia & 3 & 8.5 & tuff cone & trachyte \\
Averno & $3-4$ & 4.5 & tuff ring & trachyte \\
Montagna Spaccata & 3 & 9.7 & tuff ring & trachyte \\
Nisida & 2 & 10.6 & tuff cone & latite \\
S. Teresa & 2 & 10.6 & tuff cone & latite \\
Senga & 2 & 3.8 & cinder cone & latite \\
Monte Nuovo & 2 & $1538 \mathrm{AD}$ & cinder cone & trachyte/phonolite \\
Monte Olibano & 0 & 3.9 & lava dome & latite
\end{tabular}




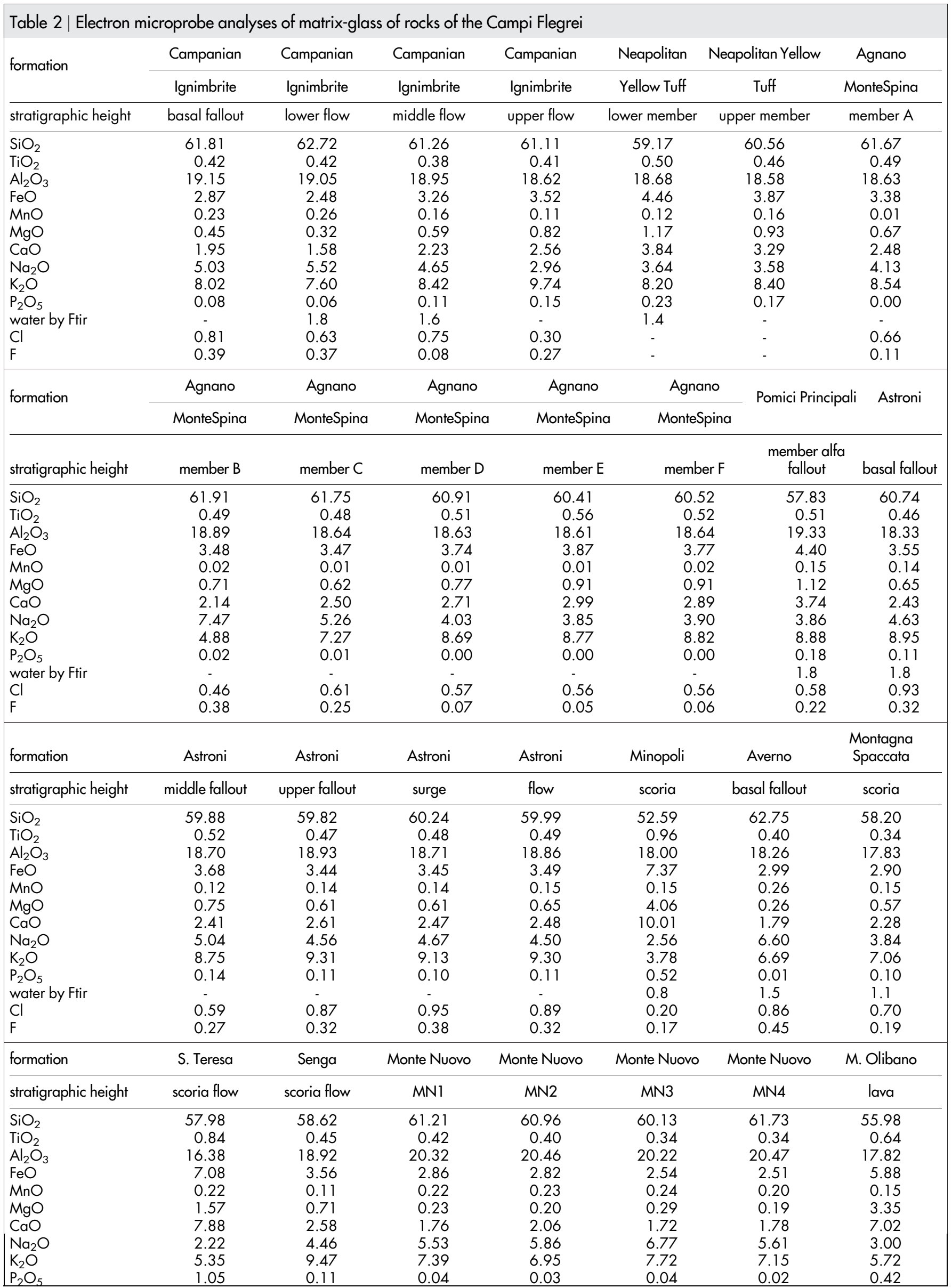




\begin{tabular}{|lccccccc|}
\hline Table 2 | Continued & & & & & & & \\
formation & S. Teresa & Senga & Monte Nuovo & Monte Nuovo & Monte Nuovo & Monte Nuovo & M. Olibano \\
\hline stratigraphic height & scoria flow & scoria flow & MN1 & MN2 & MN3 & MN4 & lava \\
\hline water by Ftir & - & 0.9 & 1.1 & 1.4 & 0.9 & - & 0.8 \\
Cl & 0.85 & 0.76 & 0.56 & 0.65 & 0.93 & 0.42 & 0.50 \\
F & 0.21 & 0.45 & 0.49 & 0.48 & 0.26 & 0.22 & 0.20 \\
\hline
\end{tabular}
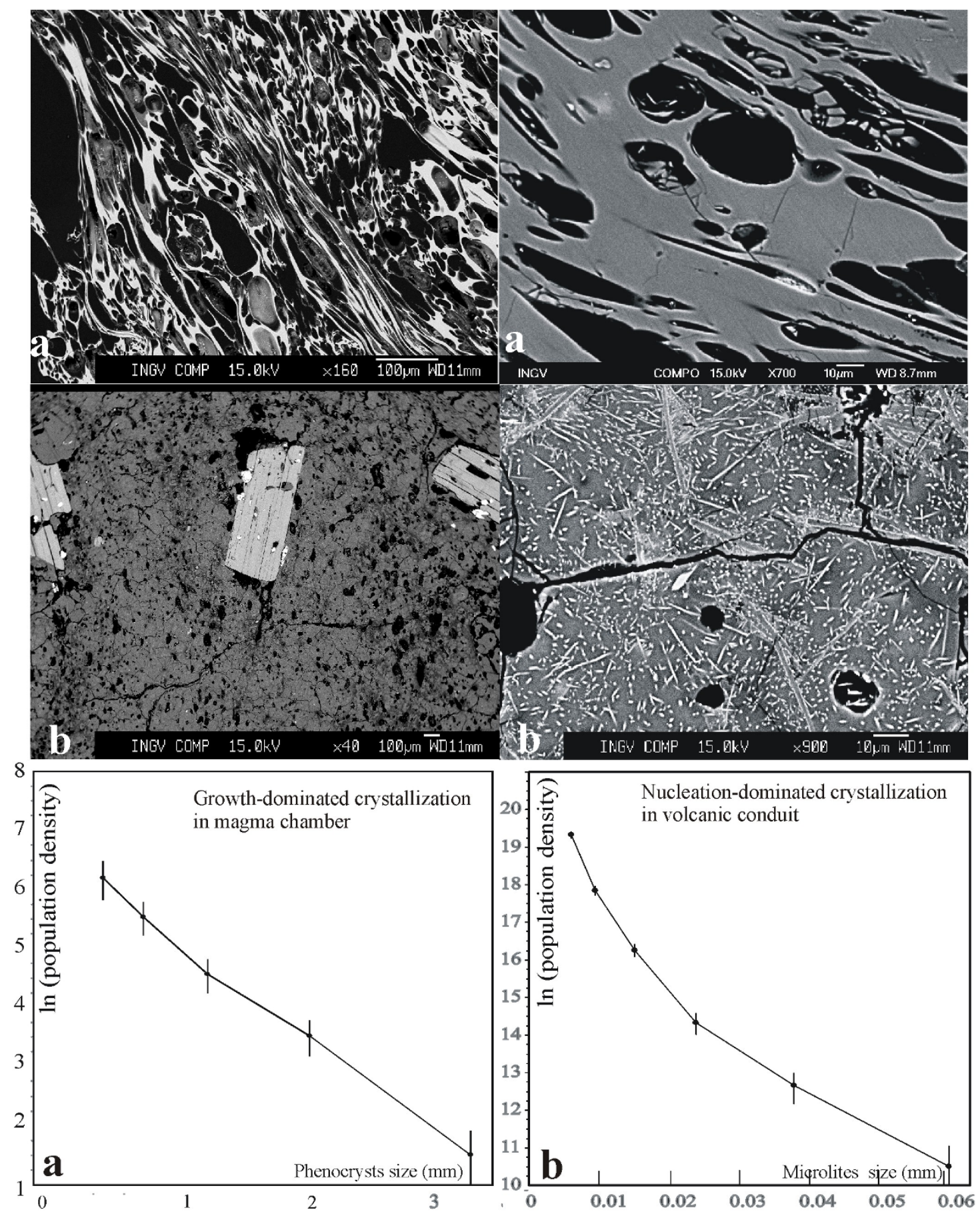

Figure 2 Back-scattered electron images of selected rocks from the Campi Flegrei caldera: (a) Campanian Ignimbrite super-eruption (39 ka), and (b) Astroni eruption $(3.7 \mathrm{ka}$ ). These images were processed using dedicated programs to obtain the CSD curves by plotting population density (number of crystals per unit volume) versus crystal size (maximum length). 
Table 3 | Textural parameters

Phenocrysts

crystal growth time

\begin{tabular}{|c|c|c|c|c|c|c|c|c|}
\hline Formation & units & bulk vesicularity & n. of crystals & Intercept $\left(\mathrm{mm}^{-4}\right)$ & Slope $\left(\mathrm{mm}^{-1}\right)$ & $\operatorname{Lmax}(\mathrm{mm})$ & time $e^{1}$ years & time $^{2}$ years \\
\hline Campanian lgnimbrite & basal fallout & 0.8 & $\ll 100$ & - & - & 1.1 & - & $17-174$ \\
\hline Campanian Ignimbrite & upper flow & 0.8 & 989 & 4.66 & -2.79 & 1.5 & $11-114$ & $24-238$ \\
\hline Neapolitan Yellow Tuff & lowe member & 0.7 & $\ll 100$ & - & - & 1 & - & $16-159$ \\
\hline Pomici Principali & basal fallout & 0.7 & $\ll 100$ & - & - & 1 & - & $16-159$ \\
\hline Astroni & basal fallout & 0.7 & 28 & 2.52 & -3 & 4 & $10-106$ & $63-634$ \\
\hline Minopoli & scoria & 0.7 & 49 & 5.52 & -4.3 & 1 & 8-78 & $16-159$ \\
\hline Nisida & scoria flow & 0.5 & 251 & 12 & -7.61 & 1.5 & $4-42$ & 24-238 \\
\hline S. Teresa & scoria flow & 0.7 & 79 & 5.26 & -5.41 & 0.6 & $6-59$ & 9-95 \\
\hline Monte Nuovo & scoria flow & 0.5 & 318 & 8.42 & -7.86 & 0.5 & $4-40$ & 8-79 \\
\hline Monte Olibano & lava dome & 0.5 & 849 & 7.32 & -3.71 & 3 & $8-85$ & $48-476$ \\
\hline
\end{tabular}

Formation

number density

Campanian Ignimbrite basal fallout

Neapolitan Yellow Tuff lower member

Agnano Monte Spina basal fallout

Pomici Principali basal fallout

Astroni

Minopoli

fallout

scoria flow

Baia

Averno

basal fallout

basal fallout

Nisida

S. Teresa

scoria flow

scoria flow

$\left(\mathrm{mm}^{-2}\right)$

n. of crystals

Intercept $\left(\mathrm{mm}^{-4}\right)$

Slope $\left(\mathrm{mm}^{-1}\right)$

$\operatorname{Lmax}(\mathrm{m})$

time' hours time ${ }^{2}$ hours

Monte Nuovo

MN1

none

$\begin{array}{ll}- & \text { none } \\ - & \text { none }\end{array}$

none

- none

$\begin{array}{rr}1.1 \mathrm{E}+05 & 1055 \\ 9.9 \mathrm{E}+02 & 197\end{array}$

$9.9 \mathrm{E}+02$

$9.4 \mathrm{E}+02$

187

$1.2 \mathrm{E}+02$

none

$9.2 \mathrm{E}+01$

734

257

$4.9 \mathrm{E}+03$

970

$3.6 \mathrm{E}+03$

723

$2.4 \mathrm{E}+03$

723
472

MN3

$9.0 \mathrm{E}+03$

1800

$5.6 \mathrm{E}+03$

1111

-
-
-
21.7
20.69
9.7
-
15
10.88
18.5
17.35
16.28
18.29
10.49

-

Monte Nuovo

lava dome

10.49

-307
-152
-23.3
-
-27
-29.8
-51.3
-25.8
-24.6
-35.5
-28.9

60

\begin{tabular}{ccc}
- & - & - \\
- & - & - \\
- & - & - \\
- & - & - \\
60 & $0.5-6$ & $5-60$ \\
38 & $1-13$ & $3-38$ \\
120 & $7-85$ & $10-120$ \\
- & - & - \\
80 & $6-74$ & $7-79$ \\
80 & $6-67$ & $7-79$ \\
80 & $3-38$ & $7-79$ \\
80 & $6-77$ & $7-79$ \\
80 & $7-81$ & $7-79$ \\
130 & $5-56$ & $10-130$ \\
120 & $6-69$ & $10-120$ \\
\hline
\end{tabular}

120

80

80

80

80

80

130

120

time 1 is calculated using crystal growth rate and CSD slopes, time 2 is calculated using crystal growth rate and the maximum measured length of crystals (Lmax), crystal growth rate range for phenocrysts: $10^{-9}-10^{-10} \mathrm{~mm} / \mathrm{s}$ (feldspar). crystal growth rate range for microlite: $1.39 \times 10^{-7}$ to $1.65 \times 10^{-6} \mathrm{~mm} / \mathrm{s}$ (feldspar).

phases, could increase the gas content of the magmas and thus the eruption explosivity. Therefore, to quantify the role of limestone contamination in the evolution of the Campi Flegrei magmatic system, stable isotope studies were carried out on minerals that were separated from rocks representing eruptions with various explosivities.

Clinopyroxene and sanidine that are separated from rock samples have similar $\delta^{18} \mathrm{O}$ values, ranging from $6.66-7.04 \%$ and $8.09-8.51 \%$, respectively. These values do not correlate with the explosivity indices of the eruptions (Figure 3; Table 4). Although the oxygen isotope fractionation factors have not been measured specifically for the alkaline Campi Flegrei rocks, various authors ${ }^{8,9}$ indicate that the clinopyroxene-sanidine fractionation varies, for silicic rocks, between $1.2-2.3 \%$ at magmatic temperatures. Therefore we consider that sanidine and clinopyroxene samples are in oxygen isotope equilibrium. Moreover, we can assume that the sanidine results closely approach magmatic values; in fact, the sanidine-melt fractionation values are typically small $(0.1-0 \%$ ) and near the limit of analytical uncertainty for silicic magmas ${ }^{8-10}$. Furthermore, these isotopic values are higher than those of parental mafic rocks $\left(5.5 \% 0,{ }^{11}\right)$, indicating that this isotopic imprint is acquired at shallow levels in the crust, and possibly reveals magma contamination by sedimentary carbonates $\left(\delta^{18} \mathrm{O}=25-28 \%{ }^{12}\right)$. According to the simple mass-balance equation (1- $\left[\left(\delta^{18} \mathrm{O}\right.\right.$ limestone $-\Delta^{18} \mathrm{Omineral} / \delta^{18} \mathrm{O}$ limestone $\left.]\right)$, assimilation of up to $3 \mathrm{wt} \%$ of sedimentary carbonates can explain the isotopic variations acquired by clinopyroxene and sanidine during their growth. This low level of contamination is in agreement with the results of an experimental study ${ }^{13}$ documenting that the assimilation of 2-5 wt\% of calcite closely reproduces a slightly undersaturated trend for $\mathrm{SiO}_{2}$, matching the trend observed in the Campi Flegrei magmatic series. Under these conditions, experimental results ${ }^{13}$ indicate that the amount of $\mathrm{CO}_{2}$ gas released is low (approximately $1 \%$ ) during assimilation, consistent with the low amount of $\mathrm{CO}_{2}$ (a few ppm) measured in the glass inclusions of Campi Flegrei sialic rocks.

Therefore, the calculated low degree of contamination, common to eruptions with a very wide range of explosivity (as indicated by the similarity in $\delta^{18} \mathrm{O}$ values measured in the selected Campi Flegrei rocks), suggests that the limestone assimilation process cannot alone be the main cause of the explosive behaviour of the Campi Flegrei magmas. Indeed, the eruption dynamics would have been mostly caused by a combination of factors such as magma volume, degree of carbonate assimilation, and the mechanism and timing of degassing processes during the magma's rise through the volcanic conduit.

Magma ascent: degassing processes in volcanic conduit. To investigate the degassing process of these melts during ascent from the magma chamber toward the surface, the vesicularity of pumice and scoria specimens was measured as well as the residual water content in their matrix glasses, which represent the magma melt fraction quenched at the time of eruption (Table 2).

The measured values of vesicularity (60-70 wt\%) of felsic pumices from highly explosive eruptions (VEI 4 to 7 ) are consistent with those calculated (following ${ }^{14}$ ) in the case of a closed-system equilibrium 

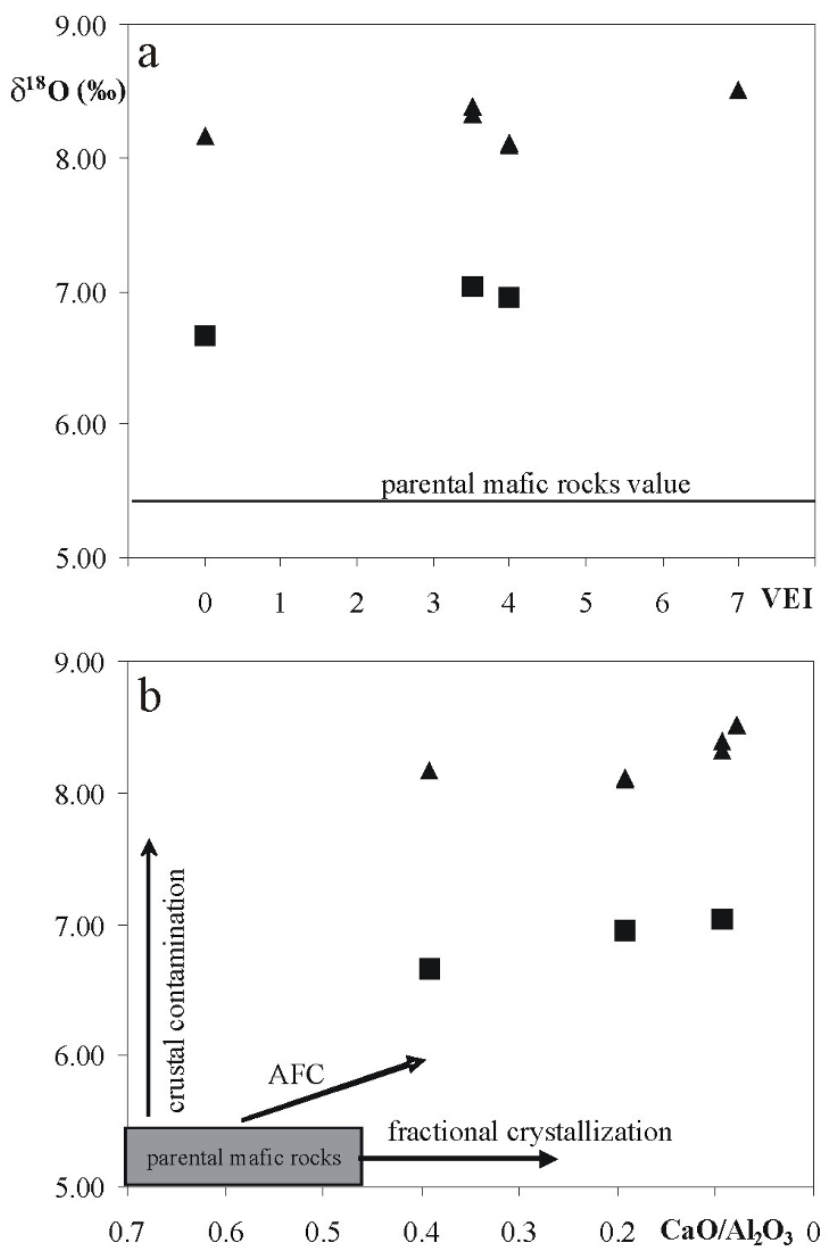

Figure 3 Oxygen isotope composition of clinopyroxene (squares) and sanidine (triangles) crystals from four main eruptive units of the Campi Flegrei caldera plotted versus (a) Volcanic Explosivity Index (VEI) and (b) $\mathrm{CaO} / \mathrm{Al}_{2} \mathrm{O}_{3}$.

degassing, with the assumption that no further degassing occurred after fragmentation. This last assumption, although not always true (e.g. ${ }^{15,16}$ ), is generally accepted for high VEI eruptions, for which the time between fragmentation and quenching in the atmosphere is on the order of seconds. Moreover, in the case of Campi Flegrei magmas, experimental studies indicate that evolved alkaline liquids, due to their lower viscosity, usually degas at equilibrium conditions over the wide range of decompression rates that is typical of most explosive eruptions (e.g. ${ }^{17,18}$ ). Consequently, under the inferred equilibrium degassing conditions, the water content measured in matrix glass closely represents the residual dissolved water content in the melt at the time of fragmentation. Considering the relationship between pressure and water content obtained experimentally for trachytic melts ${ }^{19}$ at temperatures of $850-900^{\circ} \mathrm{C}$, the measured water content in matrix glass of pumice samples (1.4 to $1.8 \mathrm{wt} \%)$ corresponds to a fragmentation pressure of 25-40 Mpa (1100-1600 m).

In contrast, the low water content ( 0.8 to $1.1 \mathrm{wt} \%)$ of scorias from VEI 2-3 eruptions indicates a quenching pressure approximately $20 \mathrm{Mpa}(800 \mathrm{~m})$. These values, associated with low vesicularity (30-40 wt\%), are direct evidence of open-system degassing, implying that gas loss occurred at shallow depth in the conduit, most likely due to low ascent rates. An exception is represented by the higher water content of sample MN2 from the phreato-magmatic units of the Monte Nuovo eruption, which is possibly related to the interaction of magma with ground water.

Timescale of magma evolution and ascent processes. To constrain the timescale of evolution of mafic magmas toward felsic compositions, and examine their eruptive ascent velocity, crystal size distribution theory $(\mathrm{CSD})^{20,21}$ has been applied. A CSD is generally shown as a semi-logarithmic plot of population density (number of crystals per unit volume) versus crystal size (maximum length) with the slope equal to 1 (growth rate $\mathrm{x}$ residence time). Thus, if the growth rate is known, the residence time can be computed.

The graphs of the distribution of crystal size in the samples show multiple slopes corresponding to phenocrysts and microlites $(<100$ micron; Fig. 2). These, according to the results of previous experiments $^{22}$, are evidence of different nucleation and under-cooling rates (Table 3) during magma crystallisation. In particular, the steep slopes ( $-23--307$, Table 3$)$ and high intercept values (9-21, Table 3$)$ of the acicular microlites suggest that they underwent rapid nucleation because of under-cooling during magma ascent and syn-eruptive degassing in the volcanic conduit ${ }^{23}$. In contrast, the flat slopes $(-2$ - -7 , Table 3) with low intercepts (2-12, Table 3) shown by the euhedral phenocrysts indicate that they grew under near-equilibrium conditions and modest cooling rates in crustal magma chambers (Figure 2).

Data on the average growth rates during the crystallisation of both phenocrysts and microlites were collected for the CSD Marsh model so that the crystal growth time could be estimated. Under conditions of slight under-cooling in magma chambers, experimental and CSD studies indicate that crystal growth rates are consistently between

\begin{tabular}{|c|c|c|c|c|c|}
\hline & clinopyroxene & & & & \\
\hline Pomici Principali & PI CPX & 1724 & 6.95 & 43 & 87 \\
\hline Monte Olibano & $\begin{array}{l}\mathrm{OL} \mathrm{CPX} \\
\text { sanidine }\end{array}$ & 1736 & 6.66 & 43 & 103 \\
\hline Pomici Principali & PPI SAN & 1722 & 8.09 & 47 & 67 \\
\hline Pomici Principali & P3 SAN & 1751 & 8.11 & 47 & 67 \\
\hline Monte Olibano & OL SAN & 1724 & 8.16 & 47 & 65 \\
\hline \multirow[t]{2}{*}{ Campanian lgnimbrite } & $\begin{array}{l}\text { TF SAN } \\
\text { Standards }\end{array}$ & 1722 & 8.51 & 47 & 70 \\
\hline & GJAG & 1732 & 5.40 & & \\
\hline
\end{tabular}

"G JAG - internal standard calibrated against the NBS-30 biotite international standard. 

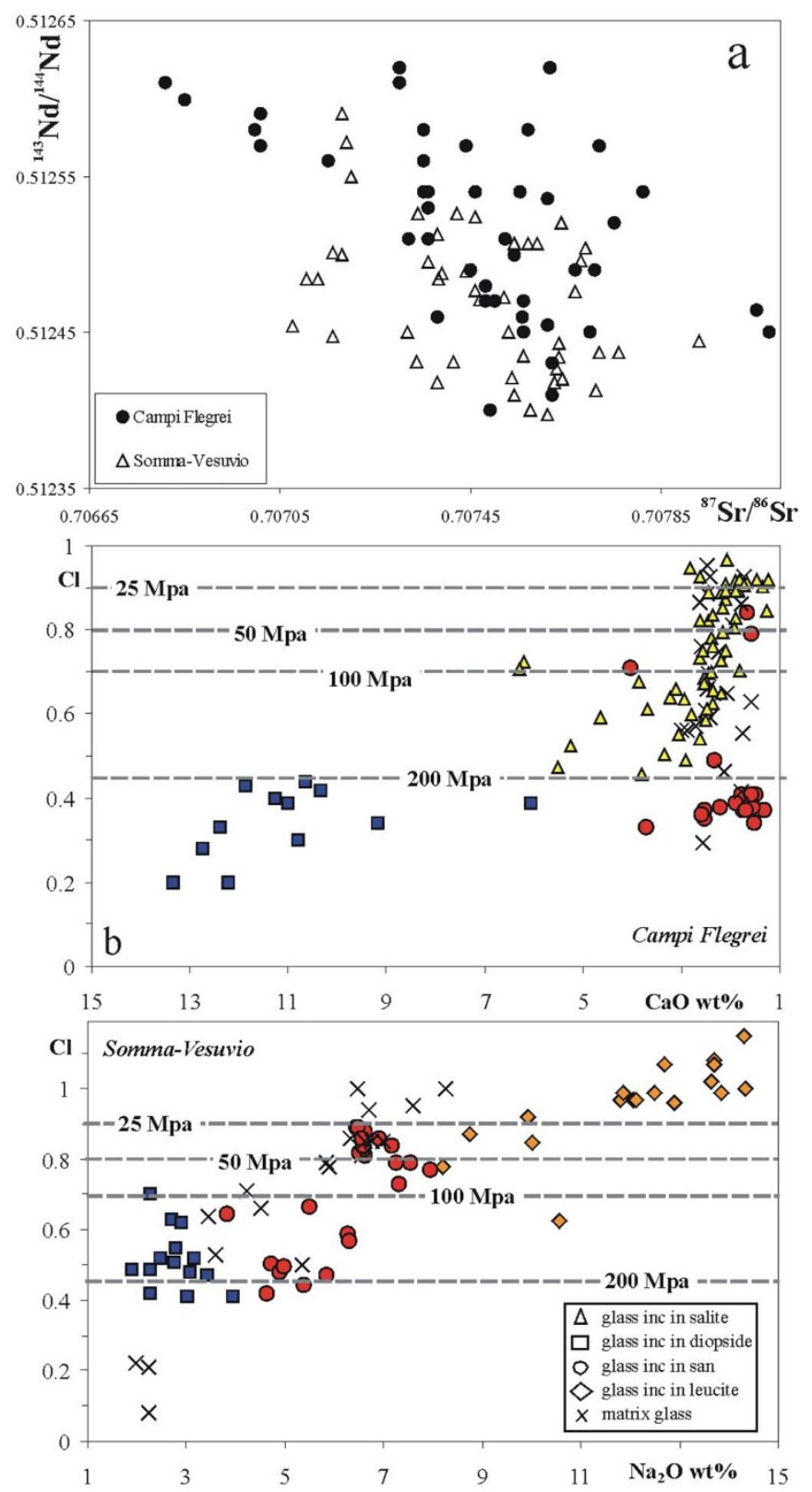

Figure $4 \mid$ (a) Sr and Nd isotopic ratios of Campi Flegrei and SommaVesuvius volcanic rocks. Isotope data from Piochi et al. ${ }^{53}$. (b) $\mathrm{Cl}$ versus $\mathrm{CaO}$ and $\mathrm{Na}_{2} \mathrm{O}$ contents of matrix glasses (this study) and melt inclusions in mineral phases (data from ${ }^{34-37}$ ). Somma-Vesuvius data are from Pappalardo and Mastrolorenzo ${ }^{3}$. Horizontal lines denote saturation pressure for different water and $\mathrm{Cl}$ contents (solubility models by ${ }^{38}$ ).

$10^{-9}$ and $10^{-10} \mathrm{~mm} / \mathrm{s}\left(\right.$ e.g. ${ }^{24-26}$ ) for intermediate to silicic magmas. In this study, the residence time was determined by CSDs of feldspars, which represent the most abundant ( $90 \%$ by volume of minerals) phase that was precipitated during the main stage of the magmatic differentiation (e.g. $\left.{ }^{4,6}\right)$. Thus, the obtained time scales may record the minimum storage time of magmas in the reservoir prior to the eruption, and may provide some insights into the approximate timescales required for the magma chamber to become supercritical.

Using the whole range of growth rates $\left(10^{-9}-10^{-10} \mathrm{~mm} / \mathrm{s}\right)$ calculated for phenocrysts, which have been used in many CSD studies $\left(\right.$ e.g. $\left.{ }^{27-31}\right)$, the CSD slopes provide an average residence time in magma chambers on the order of a few centuries (Table 3). A similar residence time can be inferred from the coarsest phenocrysts (Table 3).
Because decompression experiments indicate that the growth rate of microlites can be highly dependent on the decompression rate (e.g. ${ }^{32}$ ), in our calculations we have used the entire range of growth rates (from $1.39 \times 10^{-7}$ to $1.65 \times 10^{-6} \mathrm{~mm} / \mathrm{s}$ ) available for sanidine in the Campi Flegrei rocks. These rates were obtained by experiments ${ }^{17}$ performed at different decompression rates (time intervals between 7200 and 50,400 seconds ${ }^{33}$ ). By applying this range of growth rates to the CSD slopes of the microlite population and to the coarsest microlites, we calculate that magma ascent lasted from hours to days for low VEI events (Table 3 ). It is worth noting that decompression experiments ${ }^{22}$ have shown that the absence of microlites in the groundmass of pumices from highly explosive eruptions indicates that the magma decompression time was too short (in the order of a few hours) to generate microlites. The link between rapid magma ascent and the absence of microlites in large VEI eruptions is also confirmed by the growth rates obtained by decompression experiments on natural Campi Flegrei trachytic melts ${ }^{33}$. The absence of reaction rims on biotite crystals, which, as indicated by phase equilibrium experiments ${ }^{5}$ on Campi Flegri rocks, become unstable at pressures below $135 \mathrm{Mpa}$ in a short time span, provides yet another line of evidence.

\section{Discussion}

Our data from volcanic rocks ejected from Campi Flegrei show that the alkaline magmas evolved relatively rapidly (over centuries) toward crystal-poor felsic liquids, which were stored at a shallow pressure of ca. $150-250 \mathrm{Mpa}$ (6-10 km depth). These results on the depth and timescale of magma residence are very similar to those found for phonolites erupted from Somma-Vesuvius ${ }^{3}$, which suggests that since $50 \mathrm{ka}$, a wide common reservoir may have been active beneath the Neapolitan volcanic districts. Moreover, a unique shallower magmatic source for the two Neapolitan volcanic areas is also supported by the similarity in the $\mathrm{Sr}$ and $\mathrm{Nd}$ isotopic compositions in both silicic and mafic rocks of Campi Flegrei and Somma-Vesuvius (Figure 4A). In Figure 4B, we compare the crystallisation depth of different mineral phases of Campi Flegrei and Somma-Vesuvius magmas by using the $\mathrm{Cl}$ contents measured in matrix glasses (this study) and in melt inclusions ${ }^{34-37}$, and the values of the saturation pressure for different $\mathrm{Cl}$ contents based on the available solubility models ${ }^{38}$. In particular, the resulting trends indicate that the precipitation of diopside and sanidine occurred mostly at a maximum pressure of at least $>200-100$ Mpa for both volcanoes. Salite and leucite crystallised mostly at shallower pressures of 100-25 Mpa, most likely during a later crystallisation stage induced by magma degassing in the volcanic conduit, as their $\mathrm{Cl}$ contents match those measured in degassed matrix-glasses.

The geophysical anomalies detected by seismic tomography indicate the presence of a partial melting zone at 7-8 $\mathrm{km}$ depth beneath both Campi Flegrei and Somma-Vesuvius, while the heat flux distribution $^{39}$ shows a continuous positive anomaly in the maximum values beneath the Campi Flegrei super-volcano, where the main volume of the feeding system would be concentrated (Figure 5). Furthermore, thermal numerical models ${ }^{40}$ estimate a high volume of magma (at least $1000 \mathrm{~km}^{3}$ ) above $10 \mathrm{~km}$ beneath the caldera. On the other hand, tomographic studies ${ }^{2}$ indicate that the low velocity layer is only 1-2 km thick, which means that the large volume of magma has to be distributed as a wide sill-like layer, most likely extending beneath the whole Neapolitan volcanic area between 7$9 \mathrm{~km}$ depth, where there is an important lithological break at the transition between sedimentary and metamorphic rocks.

Our CSD data on feldspar phenocrysts indicate that this magmatic system can evolve toward less-dense felsic liquids in a time span comparable with the hundreds of years of volcano repose. This implies that a volatile-rich trachytic layer could be formed at the top of a wide magma reservoir, which could then erupt explosively. Although this scenario corresponds to the worst-case, and other less 


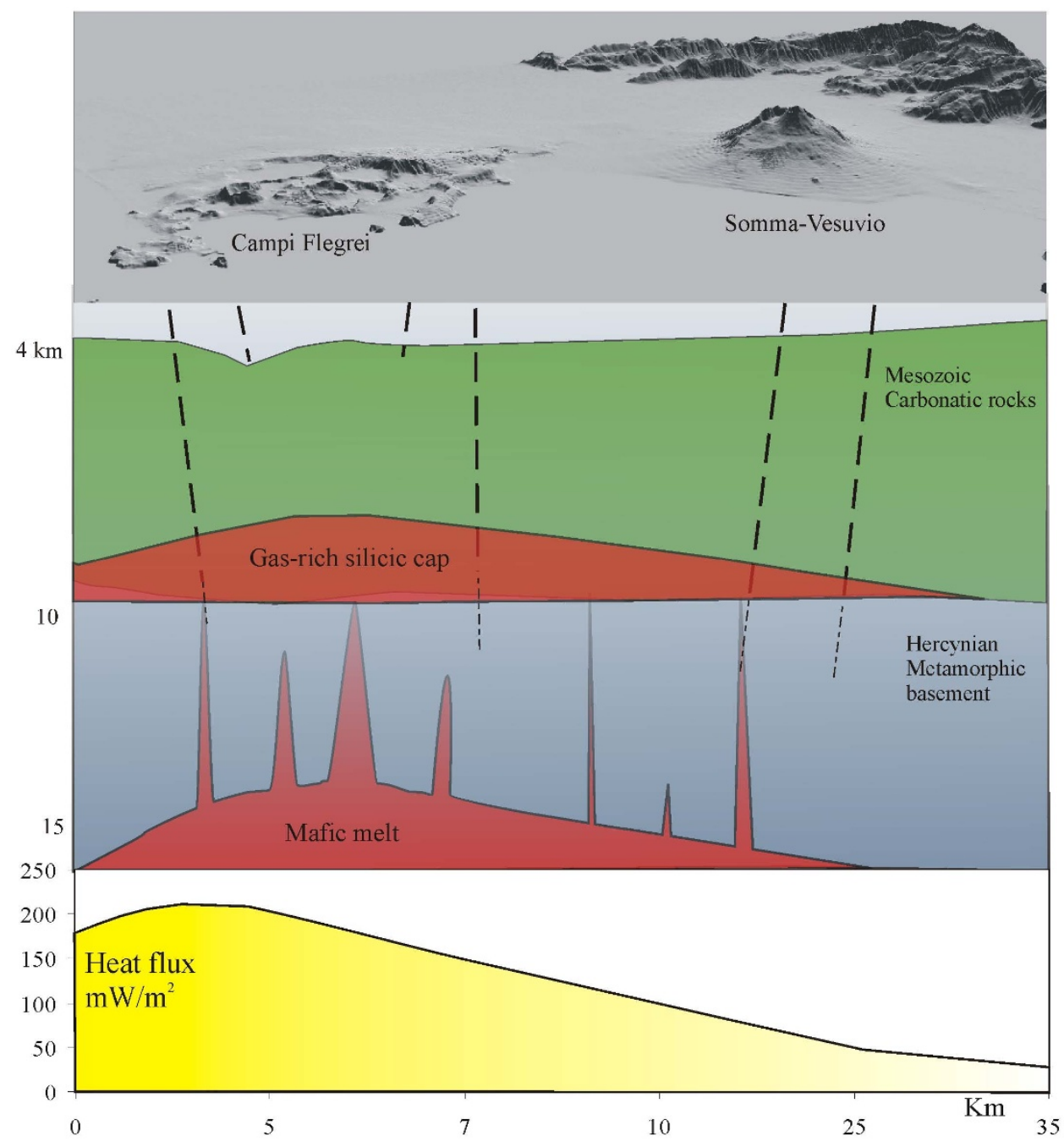

Figure $5 \mid$ Geological model of the deep structure of the Campi Flegrei caldera based on both petrological and geophysical data. DTM image of Campanian volcanoes courtesy of Laboratory of Geomatica e Cartografia, INGV-OV Naples).

severe scenarios are possible, the results of thermo-dynamical models and experiments ${ }^{5,6}$ indicate that the Campi Flegrei trachytic magmas were mainly water-saturated and were therefore capable of generating critical conditions of over-pressurisation in the chamber (5-25 Mpa, following $\left.{ }^{41}\right)$, thus triggering eruption by wall rock rupture. Also, the capability of magmas to evolve toward explosive behaviour in the relatively short time suggested by our CSDs studies (because of their water-saturated nature), implies that the current magma reservoir could be activated at any time and does not necessarily need further magmatic evolution or any external influences (e.g., recharge, water/magma interaction, assimilation) to erupt.

Our data on oxygen isotopes reveal a subordinate ( $\leq 3 \mathrm{wt} \%)$ degree of limestone contamination, causing the liberation of low amounts of $\mathrm{CO}_{2}$-rich gas phase, common to eruptions with a very wide range of VEI. These data allow us to exclude the possibility that the assimilation process alone could explain the explosivity of eruptions. Indeed, the eruption dynamics would have been mostly related to a combination of factors, such as magma volume and degree of differentiation as well as the mechanism and timing of the degassing during the magma's rise through the volcanic conduit. Notably, as revealed by our microlite size distributions, the migration of magma from the reservoir toward the surface during past explosive eruptions at Campi Flegrei has been fast, which implies that in the case of similar behaviour in a future event, there could be very little forewarning before a major eruption.
The critical state of such rapidly evolving systems was demonstrated at Rabaul caldera, in Papua New Guinea, on September 18, 1994, where a VEI 4 event occurred after only 51 years of rest time, and was proceeded by less than a day of precursors. This is particularly crucial at the Campi Flegrei caldera, where the new uplift episode that lasted from November 2004 to October 2006 has been accompanied by the almost continuous increase of the magmatic component of the fumaroles ${ }^{42}$ and seismic activity since 2000, and where a new volcanic crisis could suddenly put the densely urbanised metropolitan area of Naples at risk.

\section{Methods}

Representative well-documented eruptions with different Volcanic Explosivity Index (VEI) have been selected for the present study, (Table 1) and samples collected at different heights along the stratigraphic sequence. For each sample, bulk vesicularity measurements have been carried out for clasts within -5 and 0 phi size range, as well as electron microprobe (major and volatile elements compositions) and textural (crystal number density and size distribution) analyses of matrix-glasses and minerals by using polished thin sections. Moreover doubly-polished wafers were prepared from selected samples in order to collect Fourier Transform Infrared (FTIR) spectra for evaluating water concentration in matrix glasses. Sanidine and clinopyroxene phenocrysts have been separated from selected samples and analyzed for stable isotope measurements.

Electron microprobe analysis (EMPA). Major and volatile elements analyses of matrix glasses were performed at the CNR - Istituto di Geologia Ambientale e Geoingegneria (CNR-IGAG), Rome, using a Cameca SX-50 electron microprobe and at Istituto Nazionale di Geofisica e Vulcanologia in Rome with a JEOL-JXA-8200 
electron microprobe (WD/ED combined micro analyzer) using $15 \mathrm{kV}$ voltage, a 10 $\mu \mathrm{m}$ beam spot and $10 \mathrm{nA}$ beam current. For each analysis, a defocused beam was used to minimize losses of alkalis and volatiles, which were counted first to avoid diffusion effects. We attempted to obtain at least ten analyses for each sample. Data reduction was carried out using the ZAF4/FLS software by Link Analytical. The analytical uncertainty was about $1 \%$ for most elements. Results are reported in Table 2 .

Fourier Transform Infrared spectroscopy analysis (FTIR). To determine the water contents of glasses, FTIR analysis has been performed at the laboratory of the Dipartimento Scienze della Terra Università "Roma Tre", Rome. The IR spectra were collected using a Nicolet Magna 760 FTIR spectrometer with a KBr beam splitter and a MCT-A detector. A 30- $\mu \mathrm{m}$-diameter, doubly-polished area was examined under a Nic-Plan analytical microscope to avoid bubble and surface imperfections. Each spectrum was obtained with $4 \mathrm{~cm}-1$ resolution and 128 scans, and the background was measured during each analysis. Analytical error on any measured water content was around $10 \%$ due to uncertainty in density and glass thickness measurements and error introduced during the measurement of absorption. Results are reported in Table 2 .

Textural analysis. Textural analysis of crystal number density and size distribution was carried out on polished thin sections of epoxy-impregnated grains using a standard polarized light microscope for preliminary rock characterization followed by a Field Emission Scanning Electron Microscope (FE-SEM) JEOL JSM-6500F (Istituto Nazionale di Geofisica e Vulcanologia, Roma, Italy) for quantitative measurements. Each backscattered electron (BSE) images were processed using Adobe Photoshop and NIH Image 1.60 software to measure the number, shape, size, and volume of microlites and phenocrysts. Stereological methods have been used to convert the parameters obtained by studying two-dimensional sections into threedimensional textural values. Specifically, crystal number densities and size distributions have been obtained with the CSD Corrections 1.3 program $^{43-45}$ which includes corrections for both intersection probability and cut section effects. Emerging three-dimensional textural analysis methods ${ }^{46}$ that use serial sectioning or $\mathrm{X}$-ray tomography techniques (e.g. ${ }^{47}$ ) were not appropriate for this study because those methods require a large density contrast between crystals and matrix glass in order to achieve resolutions as small as $40 \mu \mathrm{m}$. Moreover, Mock and Jerram ${ }^{48}$ have shown that CSDs determined with two-dimensional textural data compare reasonably well with three-dimensional CSDs for sample sizes greater than 200 individual crystals and regular crystal shapes. Results are reported in Table 3.

Bulk vesicularity measurements. Bulk vesicularities have been obtained by comparing the density of juvenile vesicular clasts with the density of non-vesicular clasts for the composition of interest $\left(\mathrm{as} \mathrm{in}^{49}\right)$. In order to account for possible density variations with size, clasts within a -5 to 0 phi size range were used for density measurements. Sets of 30 clasts for each granulometric class between 0 and -5 phi were weighted and coated with a thin film of paraffin wax, and their average density was determined using a pycnometer. In order to evaluate a standard deviation for clast density within the same sample, the density of single clasts in the range of -2 to -5 phi were determined individually. The volume of the paraffin wax film has been considered negligible because its density was about equal to that of water $(1000 \mathrm{~kg} /$ $\mathrm{m} 3$ ). The average density for each sample has been calculated. Results are reported in Table 3.

Stable isotope analysis. Oxygen isotope ratios were measured at Royal Holloway, University of London (RHUL), using a Laser Fluorination Prep system with a Synrad $\mathrm{CO} 2$ Laser and BrF5 reagent on line to a GV Instrument Optima dual inlet IRMS, described in Mattey ${ }^{50}$. Optically clean sanidine and clinopyroxene separated minerals were prepared for analysis, with sample weights for each analysis around $1.7 \mathrm{mg}$. The grains were rinsed with water and ethanol, but no acid leaching was applied. Values are reported relative to V-SMOW. Two working standards, an olivine SC OLII at + $5.23 \%$ and a garnet G JAG at $+5.42 \%$, and the international biotite NBS 30 at + $5.06 \%$ were measured during the sample analytical run. Overall precision on standards and samples is better than $\pm 0.1 \%$. Results are reported in Table 4 .

1. De Natale, G., Troise, C., Pingue, F., Mastrolorenzo, G., Pappalardo, L., Battaglia, M. \& Boschi E. The Campi Flegrei Caldera, unrest mechanisms and hazards. The Geological Society, London 269, 25-45 (2006).

2. Zollo, A. et al. Seismic reflections reveal a massive melt layer feeding Campi Flegrei caldera. Geoph. Res. Lett. 35, L12306, doi: 10.1029/2008GL034242 (2008),

3. Pappalardo, L. \& Mastrolorenzo, G. Short residence times for alkaline Vesuvius magmas in a multi-depth supply system, Evidence from geochemical and textural studies. Earth Plan. Sci. Lett. 296, 133-143 (2010).

4. Pappalardo, L., Piochi, M., D’Antonio, M., Civetta, L. \& Petrini, R. Evidence for multi-stage magmatic evolution during the past $60 \mathrm{ka}$ at Campi Flegrei, Italy. deduced from $\mathrm{Sr}, \mathrm{Nd}$ and $\mathrm{Pb}$ isotope data. J. Petrol. 43(8), 1415-1434 (2002).

5. Fabbrizio, A. \& Carroll, M. Experimental constraints on the differentiation process and pre-eruptive conditions in the magmatic system of Phlegraean Fields, Naples, Italy. J. Volcanol. Geotherm. Res. 171, 88-102 (2008).

6. Pappalardo, L., Ottolini, L. \& Mastrolorenzo, G. The Campanian Ignimbrite, Southern Italy. geochemical zoning, insight on the generation of a super-eruption from catastrophic differentiation and fast withdrawal. Contrib. Mineral. Petrol. 156, 1-26 (2008)
7. Pappalardo, L., Piochi, M. \& Mastrolorenzo, G. The 3550 YR BP - 1944 AD magma-plumbing system of Somma-Vesuvius, constraints on its behavior and present state through a review of Sr-Nd isotope data. Annals of Geophysics 47, 1471-1483 (2004).

8. Bindeman, I. Oxygen Isotopes in Mantle and Crustal Magmas as Revealed by Single Crystal Analysis. Reviews in Mineralogy and Geochemistry 69, 1, 445-478 (2008).

9. Bindeman, I. N. \& Valley, J. W. Oxygen isotope study of the long Valley-Glass Mountain magmatic system, California: Isotope thermometry, and convection in large silicic magma bodies. Contrib. Minera.l Petrol. 144, 185-205 (2002).

10. Feeley, T. C., Clynne, M. A., Winer, G. S. \& Grice, W. C. Oxygen Isotope Geochemistry of the Lassen Volcanic Center, California: Resolving Crustal and Mantle Contributions to Continental Arc Magmatism. J. Petrol. 49(5), 971-997 (2008).

11. Dallai, L., Freda, C. \& Gaeta, M. Oxygene isotope geochemistry of pyroclastic clinopyroxene monitors carbonate contributions to Roman-type ultrapotassic magmas. Contrib Mineral. Petrol. 148, 247-263 (2004).

12. Turi, B. Carbon and oxygen isotopic composition of carbonates in limestone blocks and related geodes from the "Black Pozzolans" formation of the Alban Hills. Chem. Geol. 5, 195-205 (1970).

13. Marziano, G. I., Gaillard, F. \& Pichavent, M. Limestone assimilation by basaltic magmas, an experimental re-assessment and application to Italian volcanoes. Contrib. Mineral. Petrol. 155, 719-738 (2008).

14. Jaupart, C. \& Tait, S. Dynamics of eruptive phenomena. Reviews in Mineralogy and Geochemistr, 24, 1, 213-238 (1990).

15. Thomas, N., Jaupart, C. \& Vergniolle, S. On the vesicularity of pumice. J. Geophys Res. 99, 15633-15644 (1994).

16. Gardner, J. E., Thomas, R. M. E., Jaupart, C. \& Tait, S. Fragmentation of magma during plinian volcanic eruptions. Bull.Volcanol. 58, 144-162 (1996)

17. Mastrolorenzo, G. \& Pappalardo, L. Magma degassing and crystallization processes during eruptions of high-risk Neapolitan volcanoes, Evidence of common equilibrium rising processes in alkaline magmas. Earth Plan. Sci. Lett. 250, 164-181 (2006).

18. Mongrain, J., Larsen, J. F. \& King, P. L. Rapid water exsolution, degassing, and bubble collapse observed experimentally in K-phonolite melts. J. Volcanol. Geotherm. Res. 173, 178-184 (2008).

19. Di Matteo, V., Carroll, M. R., Beherens, H., Vetere, F. \& Brooker, R. A. Water solubility in trachytic melts. Chem. Geol. 213, 187-196 (2004).

20. Randolf, A. D. \& Larson, M. A. Theory of Particulate Processes, NewYork, Academic Press. (1971).

21. Marsh, B. Crystal size distribution (CSD) in rocks and the kinetics and dynamics of crystallization I. Theory. Contrib. Mineral. Petrol. 99, 277-291 (1988).

22. Couch, S. Experimental investigation of crystallization kinetics in a haplogranite system. Am. Mineral. 88, 1471-1485 (2003).

23. Hammer, J. E., Cashman, K. V. \& Voight, B. Magmatic processes revealed by textural and compositional trends in Merapi dome lavas. J. Volcanol. Geotherm. Res. 100, 165-192 (2000).

24. Cashman, K. V. Groundmass crystallization of Mount St. Helens Dacite, 19801986-A tool for interpreting shallow magmatic processes. Contrib. Mineral. Petrol. 109, 431-449 (1992).

25. Cashman, K. V. Relationship between plagioclase crystallization and cooling rate in basaltic melts. Contrib. Mineral. Petrol. 113, 126-142 (1993).

26. Morgan, D. J., Blake, S. \& Rogers, N. W. Crystallization rate and residence times of sanidine phenocrysts in the AD 472, Pollena eruption of Vesuvius. Geophysical Research Abstracts, Vol. 5, 09352, European Geophysical Society (2003).

27. Higgins, M. D. Magma dynamics beneath Kameni volcano, Greece, as revealed by crystal size and shape measurements. J. Volcanol. Geotherm. Res. 70, 37-48 (1996).

28. Jerram, D. A., Cheadle, M. J. \& Philpotts, A. R. Quantifying the building blocks of igneous rocks, Are clustered crystal frameworks the foundation? J. Petrol. 44, 11, 2033-2051 (2003).

29. Higgins, M. D. \& Roberge, J. Three magmatic components in the 1973 eruption of Eldfell volcano, Iceland, evidence from plagioclase crystal size distribution (CSD) and geochemistry. J Volcanol Geotherm Res 161, 247-260 (2007).

30. Cigolini, C., Laiolo, M. \& Bertolino, S. Probing Stromboli volcano from the mantle to paroxysmal eruptions. In, Annen C, Zellmer GF, editors. Dynamics of Crustal Magma Transfer, Storage and Differentiation: Geological Society, London, Special Publications 304, 33-70 (2008).

31. Salisbury, M. J., Bohrson, W. A., Clynne, M., Ramos, F. C. \& Hoskin, P. Multiple Plagioclase Crystal Populations Identified by Crystal Size Distribution and in situ Chemical Data: Implications for Timescales of Magma Chamber Processes Associated with the 1915 Eruption of Lassen Peak, CA. J. Petrol. 49, 1755-1780 (2008).

32. Brugger, C. R. \& Hammer, J. E. Crystal size distribution analysis of plagioclase in experimentally decompressed hydrous rhyodacite magma. Earth Planet. Sci. Lett. 300, 246-254 (2010).

33. Calzolaio, M., Arzilli, F. \& Carroll, M. R. Growth rate of alkali feldspars in decompression-induced crystallization experiments in a trachytic melt of the Phlegraean Fields (Napoli, Italy). Eur. J. Mineral. 22(4), 485-493 (2010).

34. Arienzo, I., Moretti, R., Civetta, L., Orsi, G. \& Papale P. The feeding system of Agnano-Monte Spina eruption (Campi Flegrei, Italy): Dragging the past into present activity and future scenarios. Chem. Geol. 270(1-4), 135-147 (2010). 
35. Cannatelli, C. et al. Geochemistry of melt inclusions from the Fondo Riccio and Minopoli 1 eruptions at CampiFlegrei (Italy). Chem. Geol. 237(3-4), 418-432 (2007).

36. Fourmentraux, C, Metrich, N., Bertagnini, A. \& Rosi, M. Crystal fractionation, magma step ascent, and syn-eruptive mingling: the Averno 2 eruption (Phlegraean Fields, Italy). Contrib. Mineral. Petrol. 163, 1121-1137 (2012).

37. Marianelli, P., Sbrana, A. \& Proto, M. Magma chamber of the Campi Flegrei supervolcano at the time of eruption of the Campanian Ignimbrite. Geology 34, 11, 937-940 (2006).

38. Carroll, M. R. Chlorine solubility in evolved alkaline magmas. Ann. Geophys. 48, 619-631 (2005).

39. Della Vedova, B., Bellani, S., Pellis, G. \& Squarci, P. Deep temperatures and surface heat-flow distribution. In, Anatomy of an Orogen, the Apennines and Adjacent Mediterranean Basins, G.B Vai and L.P. Martini, eds. Kluwer Academic Publishers, Dordrecht, 4656 pp. (2001).

40. Wholetz, K., Civetta, L. \& Orsi, G. Thermal evolution of the Phlegraean magmatic system. J. Volcanol. Geotherm. Res. 91, 381-414 (1999).

41. Blake, S. Volatile oversaturation during the evolution of silicic magma chambers as an eruption trigger. J. Geophys. Res. 89, 8237-8244 (1984).

42. Chiodini, G., Caliro, S., De Martino, P., Avino, R. \& Gherardi, F. Early signals of new volcanic unrest at Campi Flegrei caldera? Insights from geochemical data and physical simulations. Geology, first published on July 23, 2012, doi:10.1130/ G33251.1.

43. Higgins, M. D. Measurement of Crystal Size Distributions. Am. Mineral. 85 1105-1116 (2000).

44. Higgins, M. D. Closure in crystal size distributions (CSD), verification of CSD calculations and the significance of CSD fans. Am. Mineral. 87, 171-175 (2002).

45. Higgins, M. D. Quantitative textural measurements in igneous and metamorphic petrology. Book. Cambridge University Press, 270 pages, (2006).

46. Jerram, D. A. \& Higgins, M. D. 3D analysis of rock textures: quantifying igneous microstructures. Elements 3(4), 239-245 (2007).

47. Gualda, G. A. R. Crystal size distributions derived from 3D datasets: sample size versus uncertainties. J. Petrol. 47, 1245-1254 (2006).

48. Mock, A. \& Jerram, D. A. Crystal size distributions (CSD) in three dimensions: insights from the 3D reconstruction of a highly porphyritic rhyolite. J. Petrol. 46, 1525-1541 (2005).

49. Houghton, B. F. \& Wilson, C. J. N. A vesicularity index for pyroclastic deposits. Bull. Volcanol. 51, 451-462 (1989).
50. Mattey, D. P. LaserPrep, An Automatic Laser-Fluorination System for Micromass "Optima" or "Prism" Mass Spectrometers. Micromass Application Note 107, 8 pp (1997).

51. Rosi, M. \& Sbrana, A. Phlegrean Fields. CNR, Quad Ric. Sci. 114, 175 pp. (1987).

52. Florio, G., Fedi, M., Cella, F. \& Rapolla, A. The Campanian Plain and Phlegrean Fields, structural setting from potential field data. J Volcanol Geotherm Res. 91, 361-379 (1999)

53. Piochi, M., Pappalardo, L. \& De Astis, G. Geochemical and Isotopical variation within the Campanian Comagmatic province: implications on magma source composition. Annals of Geophysics 47, 1485-1499 (2004).

\section{Acknowledgements}

The authors wish to thank M. Serracino (CNR-IGAG, Rome) for kind assistance with electron microprobe analyses and A. Cavallo (INGV-Rome) for help during FE-SEM observations and electron microprobe analyses. We are thankful to G. Della Ventura (Università "Roma Tre", Rome, Italy) for assistance with FT-IR analyses. Matthew Thirlwall and Dave Lowry (Royal Holloway University of London) are gratefully acknowledged for allowing oxygen isotope analyses.

\section{Author contributions}

LP defined the project strategy and performed geochemical, textural and isotopic analyses. LP and GM discussed the results and wrote the manuscript.

\section{Additional information} Competing financial interests: The authors declare no competing financial interests.

License: This work is licensed under a Creative Common

Attribution-NonCommercial-NoDerivative Works 3.0 Unported License. To view a copy of this license, visit http://creativecommons.org/licenses/by-nc-nd/3.0/

How to cite this article: Pappalardo, L. \& Mastrolorenzo, G. Rapid differentiation in a sill-like magma reservoir: a case study from the campi flegrei caldera. Sci. Rep. 2, 712; DOI:10.1038/srep00712 (2012). 